\title{
Cytotoxic lymphocytes in COPD airways: increased NK cells associated with disease, iNKT and NKT-like cells with current smoking
}

\author{
Jonas Eriksson Ström ${ }^{1 *}$ (D) Jamshid Pourazar ${ }^{1}$, Robert Linder ${ }^{1}$, Anders Blomberg ${ }^{1}$, Anne Lindberg ${ }^{1}$, Anders Bucht ${ }^{2}$ \\ and Annelie F. Behndig' ${ }^{1}$
}

\begin{abstract}
Background: Cytotoxic lymphocytes are increased in the airways of COPD patients. Whether this increase is driven primarily by the disease or by smoking is not clear, nor whether it correlates with the rate of decline in lung function.

Methods: Bronchoscopy with BAL was performed in 52 subjects recruited from the longitudinal OLIN COPD study according to pre-determined criteria; 12 with COPD and a rapid decline in lung function (loss of $\mathrm{FEV}_{1} \geq 60 \mathrm{ml} /$ year), 10 with COPD and a non-rapid decline in lung function (loss of FEV $1 \leq 30 \mathrm{ml} /$ year), 15 current and ex-smokers and 15 non-smokers with normal lung function. BAL lymphocyte subsets were determined using flow cytometry.

Results: In BAL fluid, the proportions of NK, iNKT and NKT-like cells all increased with pack-years. Within the COPD group, NK cells - but not iNKT or NKT-like cells - were significantly elevated also in subjects that had quit smoking. In contrast, current smoking was associated with a marked increase in iNKT and NKT-like cells but not in NK cells. Rate of lung function decline did not significantly affect any of the results.
\end{abstract}

Conclusions: In summary, increased proportions of NK cells in BAL fluid were associated with COPD; iNKT and NKT-like cells with current smoking but not with COPD. Interestingly, NK cell percentages did not normalize in COPD subjects that had quit smoking, indicating that these cells might play a role in the continued disease progression seen in COPD even after smoking cessation.

Trial registration: Clinicaltrials.gov identifier NCT02729220.

Keywords: Chronic obstructive pulmonary disease, Disease mechanisms, Lung function decline, Smoking habits, Bronchoalveolar lavage

\section{Background}

In COPD patients, the airway lumen is infiltrated by $\mathrm{T}$ cells and increased numbers of neutrophils and macrophages $[1,2]$. The latter are thought to be the orchestrators of the inflammation, releasing chemokines that attract $\mathrm{T}$ cells and other lymphocytes, monocytes and neutrophils as well as mediating the release of proteases such as MMP-9 [3].

Among $\mathrm{T}$ cells, cytotoxic $\mathrm{CD}^{+}$cell types predominate [4]. The reason for this is not fully understood, but bacterial

\footnotetext{
* Correspondence: jonas.eriksson.strom@umu.se

${ }^{1}$ Department of Public Health and Clinical Medicine, Division of Medicine,

Umeå University, 90187 Umeå, Sweden

Full list of author information is available at the end of the article
}

colonization and viral infections have been suggested to activate the cytotoxic response [5]. The proportions of natural killer (NK) [6], natural killer T (NKT)-like [6] and invariant natural killer [7] (iNKT; sometimes also referred to as NKT Type I or Classical NKT cells [8]) are also increased in the airways of COPD patients, but the role of these cells in the pathogenesis of the disease and whether this increase is in fact due to COPD or to current smoking is not clear [9].

Taken together, the above described immunological changes are thought to be signs of a state of chronic inflammation, which over time leads to structural transformation of the airways, airway obstruction and respiratory symptoms [10]. However, the pace at which these changes occur

(c) The Author(s). 2018 Open Access This article is distributed under the terms of the Creative Commons Attribution 4.0 International License (http://creativecommons.org/licenses/by/4.0/), which permits unrestricted use, distribution, and 
- i.e. the rate of disease progression - varies greatly between individuals [11]. A rapid annual decline in lung function (LF) has been recognized as a clinical phenotype of COPD [12] and is associated with a poor prognosis [11]. Smoking cessation is known to reduce the rate of decline [12], but beyond that the reason why some patients experience a more rapid and some a slower disease progression is not well understood.

In this study, the aim was to assess the distribution of cytotoxic lymphocytes in COPD in general and their association with disease status, smoking status and a rapid/nonrapid decline in LF in particular.

\section{Methods}

\section{Subjects}

52 subjects participated in this cross-sectional study; 12 with COPD and a rapid decline in LF, 10 with COPD and a non-rapid decline in LF, 15 current and ex-smokers with normal LF (Ever-smokers) and 15 non-smokers with normal LF (Non-smokers).

All subjects were recruited, according to pre-determined criteria, from the longitudinal OLIN COPD study [13], providing spirometry data over time. The recruitment process has been described in a previous report on the 'Respiratory and Cardiovascular Effects in COPD' (KOLIN) project [14].

COPD was defined using the Global Initiative for Obstructive Lung Disease (GOLD) spirometric criterion [15]; all COPD subjects had GOLD spirometric grades $2-3$ at time of inclusion. Rapid decline was defined as a loss of forced expiratory volume in one second $\left(\mathrm{FEV}_{1}\right) \geq 60 \mathrm{ml} /$ year and non-rapid decline as a loss $\leq 30 \mathrm{ml} /$ year; both measured over a period of at least five years and calculated using data from the OLIN COPD study as $\left(\mathrm{FEV}_{1}\right.$ at recruitment - $\mathrm{FEV}_{1}$ at follow-up)/number of years of follow-up [14]. COPD and Ever-smokers groups consisted of both current and ex-smokers, all with a smoking history of at least 10 pack-years. Ex-smokers had stopped smoking since at least 12 months. Subjects with medical conditions contradicting bronchoscopy and/or inflammatory conditions or medication expected to affect the outcome of the study were excluded from participation [14]. Subject demographics and basic characteristics are given in Table 1.

\section{Study design}

The current study was divided into three parts, each testing a separate hypothesis. Groups were either merged or divided into subgroups depending on the hypothesis tested (Fig. 1).

In part 1 the inflammatory characteristics and distribution of cytotoxic lymphocytes were examined using as big groups as possible. It was hypothesized that COPD would be associated with elevated proportions of cytotoxic lymphocytes and therefore all COPD subjects (current and ex-smokers) were compared to to Ever-smokers and Non-smokers.
In part 2 the hypothesis was that some of the differences found in part 1 would be associated with current smoking and others with COPD. To separate between these, we compared 1) COPD current smokers to COPD ex-smokers; differences between these groups would likely be related to smoking status (since disease status is the same for both groups); and 2) COPD ex-smokers to ex-smokers with normal LF; differences between these groups would likely be related to disease status (since smoking status is the same for both groups).

In part 3 COPD subjects were split into two groups according to rate of decline in LF to test the hypothesis that some of the differences found in part 1 would be associated with a rapid decline.

\section{Spirometry}

Dynamic spirometry variables were measured using a dry volume spirometer, Mijnhardt Vicatest 5, the Netherlands, following the American Thoracic Society/European Respiratory Society guidelines [16]. Vital Capacity (VC) was defined as the highest value of forced and slow vital capacity. If $\mathrm{FEV}_{1}$ was lower than $80 \%$ of predicted (using Swedish spirometric reference values [17]) or if $\mathrm{FEV}_{1} / \mathrm{VC}$ was below 0.70 , reversibility testing was performed. The highest value out of pre- and post-bronchodilatation $\mathrm{FEV}_{1}$ and $\mathrm{VC}$ was used in the analysis.

\section{Bronchoscopy}

All bronchoscopies were performed by one medical team but at two different locations - the Division of Respiratory Medicine and Allergy, Department of Medicine, Sunderby Central Hospital of Norrbotten, Luleå, Sweden and the Division of of Respiratory Medicine and Allergy, Department of Medicine, University Hospital, Umeå, Sweden. Topical anesthesia was achieved using lidocaine. Subjects were premediated with $1.0 \mathrm{mg}$ of atropine given subcutaneously $30 \mathrm{~min}$ before the procedure, some also received midazolam 4-8 mg per os. A flexible video bronchoscope was inserted through the mouth via a mouthpiece with the subject in the supine position. Bronchoalveolar lavage (BAL) was performed by infusing three aliquots of $60 \mathrm{ml}$ of sterile sodium chloride $(0.9 \%), \mathrm{pH} 7.3$ at $37^{\circ} \mathrm{C}$ in the middle lobe or lingula, the fluid was gently sucked back after each infusion and pooled into a tube placed in iced water. The recovered BAL fluid (BALF) was immediately transported to the laboratory for analysis. Bronchial wash $(2 \times 20 \mathrm{ml})$ and biopsies were also performed but not included in the analysis in the current study.

BAL could not be performed on three COPD subjects due to problems tolerating the bronchoscopy procedure. In one COPD subject, BALF recovery was too low to perform flow cytometry analysis, although differential cell count of leukocytes was possible. No exacerbations were reported in the four weeks prior to bronchoscopy. 
Table 1 Basic characteristics of the study population, by spirometry classification and smoking status

Part 1: Characterizing the inflammation

\begin{tabular}{|c|c|c|c|}
\hline & $\begin{array}{l}\text { All COPD subjects } \\
\text { (COPD) } \\
n=22\end{array}$ & $\begin{array}{l}\text { Ever-smokers with normal LF } \\
\text { (EvS) } \\
n=15\end{array}$ & $\begin{array}{l}\text { Non-smokers with normal LF } \\
\text { (NoS) } \\
n=15\end{array}$ \\
\hline Female:Male & $6: 16$ & $8: 7$ & $4: 11$ \\
\hline $\mathrm{Age}^{\mathrm{a}}$ & $65 \pm 7$ & $67 \pm 6$ & $66 \pm 8$ \\
\hline$B M I^{b}$ & $26 \pm 3$ & $26 \pm 2$ & $28 \pm 5$ \\
\hline Current:Ex-smokers ${ }^{b}$ & $11: 11$ & $3: 12$ & $0: 0$ \\
\hline Pack-years $^{b}$ & $36 \pm 14$ & $18 \pm 9$ & 0 \\
\hline $\mathrm{FEV}_{1}$, percent of predicted ${ }^{\mathrm{a}}$ & $61.5 \pm 17$ & $108 \pm 19$ & $103 \pm 17$ \\
\hline $\mathrm{FEV}_{1} \mathrm{NC}^{\mathrm{a}}$ & $0.53 \pm 0.11$ & $0.73 \pm 0.04$ & $0.78 \pm 0.04$ \\
\hline BAL-recovery, ${ }^{c}$ & $42 \pm 17$ & $61 \pm 12$ & $63 \pm 10$ \\
\hline Annual decline in $\mathrm{FEV}_{1}, \mathrm{ml}^{\mathrm{a}}$ & $57 \pm 42$ & NA & NA \\
\hline Rapid:Non-rapid decline ${ }^{b}$ & $12: 10$ & NA & NA \\
\hline
\end{tabular}

NS

NS

$\mathbf{p}=\mathbf{0 . 0 0 0 2}$ COPD vs Evs; $\mathrm{p}<\mathbf{0 . 0 0 0 1}$ COPD VS NOS

$\mathbf{p}<\mathbf{0 . 0 0 0 1}$ COPD VS EvS; $\mathbf{p}<\mathbf{0 . 0 0 0 1}$ COPD vs NoS; $\mathbf{p}<\mathbf{0 . 0 0 0 1}$ COPD vs EvS; $\mathbf{p}<\mathbf{0 . 0 0 0 1}$ COPD vs NoS; $\mathbf{p}=\mathbf{0 . 0 0 0 6}$ COPD vs EvS: $\mathbf{p}=\mathbf{0 . 0 0 0 1}$ COPD vS NoS

Part 2: Separating the effect of smoking from that of COPD

\begin{tabular}{|c|c|c|c|}
\hline & $\begin{array}{l}\text { COPD current smokers } \\
\text { (CCuS) } \\
n=11\end{array}$ & $\begin{array}{l}\text { COPD ex-smokers } \\
\text { (CExS) } \\
n=11\end{array}$ & $\begin{array}{l}\text { Ex-smokers with normal LF } \\
\text { (ExS) } \\
n=12\end{array}$ \\
\hline Female:Male ${ }^{a}$ & $2: 9$ & $4: 7$ & $6: 6$ \\
\hline $\mathrm{Age}^{\mathrm{a}}$ & $61 \pm 5$ & $69 \pm 6$ & $67 \pm 7$ \\
\hline $\mathrm{BMI}^{\mathrm{b}}$ & $25 \pm 4$ & $26 \pm 2$ & $26 \pm 2$ \\
\hline Pack-years ${ }^{b}$ & $38 \pm 9.3$ & $33 \pm 18$ & $18 \pm 9$ \\
\hline $\mathrm{FEV}_{1}$, percent of predicted ${ }^{\mathrm{a}}$ & $61 \pm 16$ & $62 \pm 18$ & $107 \pm 17$ \\
\hline $\mathrm{FEV}_{1} / \mathrm{NC}^{\mathrm{a}}$ & $0.53 \pm 0.12$ & $0.53 \pm 0.12$ & $0.73 \pm 0.04$ \\
\hline BAL-recovery, $\%^{\mathrm{c}}$ & $47 \pm 17$ & $37 \pm 17$ & $64 \pm 7$ \\
\hline Annual decline in $\mathrm{FEV}_{1}, \mathrm{ml}^{\mathrm{a}}$ & $73 \pm 44$ & $39 \pm 36$ & NA \\
\hline Rapid:Non-rapid decline ${ }^{b}$ & $8: 3$ & $4: 7$ & NA \\
\hline
\end{tabular}

$\mathbf{p}=\mathbf{0 . 0 0 4 8}$ CCUS vs CExS NS

$\mathbf{p}=\mathbf{0 . 0 4 4 4}$ CCUS vS CEXS; $\mathbf{p}=\mathbf{0 . 0 1 5 8} C$ CXS VS EXS $\mathbf{p}<\mathbf{0 . 0 0 0 1}$ CEXS vs EXS

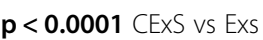
$\mathbf{p}<\mathbf{0 . 0 0 0 1}$ CEXS vs EXS $\mathbf{p}=\mathbf{0 . 0 1 9 9}$ CCuS vs CExS

Part 3: COPD and a rapid/non-rapid of decline in lung function

$\begin{array}{llll} & \text { COPD rapid decline in LF } & \text { COPD non-rapid decline in LF } & p \\ & n=12 & n=10 & \\ \text { Female:Male } & 2: 10 & 4: 6 & \\ \text { Age }^{a} & 63 \pm 7 & 67 \pm 6 & \mathbf{p}=\mathbf{0 . 0 3 5 8} \\ \text { BMl }^{\mathrm{b}} & 26 \pm 3 & 25 \pm 3 & \mathrm{NS} \\ \text { Current:Ex-smokers }^{\mathrm{b}} & 8: 4 & 3: 7 & \\ \text { Pack-years }^{\mathrm{b}} & 37.5 \pm 16 & 33 \pm 11 & \mathrm{NS} \\ \text { FEV }_{1}, \text { percent of predicted }^{\mathrm{a}} & 60 \pm 15 & 63 \pm 19 & \mathrm{NS} \\ \text { FEV }_{1} \text { NCC }^{\text {a }} & 0.52 \pm 0.12 & 0.54 \pm 0.11 & \mathrm{NS} \\ \text { BAL-recovery, }^{\mathrm{c}} & 44 \pm 16 & 40 \pm 19 & \mathrm{NS} \\ {\text { Annual decline in } \mathrm{FEV}_{1}, \mathrm{ml}^{\mathrm{a}}} & 86 \pm 29 & 16 \pm 16 & \mathbf{p}<\mathbf{0 . 0 0 0 1}\end{array}$

Values given as mean \pm SD unless indicated differently. Statistical comparisons between the three groups were made using Kruskal Wallis test and a $p$-value $<0.05$ was considered significant. If the Kruskal Wallis test indicated significance, the Mann-Whitney U-test was used for post hoc analysis. NS: Not significant. Pack-years: (number of cigarettes smoked per day/20) $\times$ number of years smoked. FEV ${ }_{1}$ Forced Expiratory Volume in one second. VC: Vital Capacity. Annual Decline in FEV ${ }_{1}$, ml: calculated using data from the OLIN COPD study as (FEV 1 at recruitment - $\mathrm{FEV}_{1}$ at follow-up)/number of years of follow-up, based on highest value pre- or post-bronchodilation

${ }^{a}$ At inclusion in the current study

${ }^{\mathrm{b}}$ At identification in the OLIN COPD study

${ }^{\mathrm{c} A t}$ time of bronchoscopy in the current study 

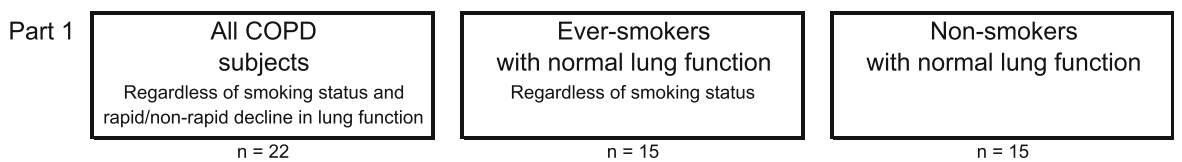

Hypothesis: COPD would be associated with elevated proportions of cytotoxic lymphocytes compared to other groups

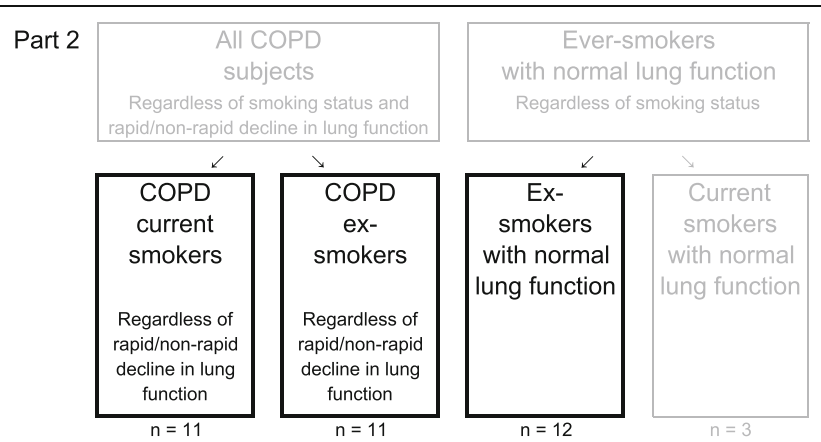

Hypothesis: Some of the differences found in Part 1 would be associated with COPD, others with current smoking

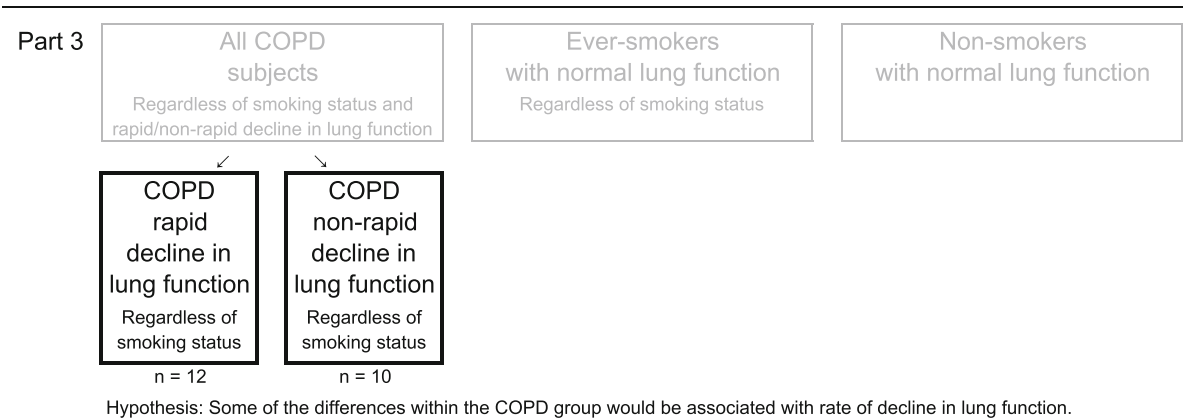

Fig. 1 Study design

\section{Flow cytometry analysis}

Cell staining and data acquisition were performed at one centralized location. BALF lymphocyte subsets were determined using a FACSCalibur ${ }^{\mathrm{TM}}$ (Becton Dickinson) flow cytometer. BALF cells were centrifuged and adjusted to a final concentration of $10^{6}$ cells $/ \mathrm{ml}$. For each test, different antibody panels conjugated with either phycoerytrin-Cy5 (PE Cy5), fluorescein isothiocyanate (FITC), phycoerytrin (PE), Allophycocyanin (APC), Peridinin Chlorophyll Protein Complex (PerCP) or Peridinin Chlorophyll Protein Complex-Cy5.5 (PerCPCy5.5) were combined. Appropriate isotype-matched controls were used in all experiments. The suppliers for the antibodies against TCR V $\beta 11$ and TCR V 24 were Beckman Coulter (Brea, CA, USA) and eBiodcience, Inc. (Thermo Fisher Scientific, Sweden) respectively, whereas the remaining antibodies used in this investigation were purchased from Becton Dickinson (San Jose, CA, USA). Each test tube contained 200-400 $\mu \mathrm{l}$ of cell suspension $\left(10^{6}\right.$ cells $\left./ \mathrm{ml}\right)$ to which $10 \mu \mathrm{l}$ of each antibody was added. After the staining procedure [18], analysis was performed using FACSCalibur ${ }^{\mathrm{rm}}$. The lymphocyte population was gated based on the cells' physical characteristics in a region according to their characteristic forward scatter (FCS) and side scatter (SSC) profiles. 60009000 cells were collected in $\mathrm{CD}^{+}$gate per test tube and percentage of CD3 subpopulation was counted out of gated $\mathrm{CD}^{+}$lymphocytes and furthermore out of gated subpopulations (Table 2). To ensure that autofluorescence did not influence the results, we stained for CD45/CD14 and compared that to the results of lymphocyte and macrophage gating. Flow cytometry data were acquired and analysed using CellQuest Software (Becton Dickinson).

\section{Statistical analysis}

To analyze the data, a two-step approach was used. In the first step, the investigated cell populations and subpopulations were analyzed using group-wise comparisons. For statistical comparisons between more than two groups, the Kruskal-Wallis test was used and a $p$-value $<0.05$ was considered significant. If the Kruskal-Wallis test indicated significance, the Mann-Whitney U-test was carried out for post-hoc comparison between two groups. In the second step, cytotoxic cell populations with significant betweengroup differences were examined further using multivariable mixed effects regression models. These models were performed by specifying the response variable as the number of 
Table 2 Lymphocyte populations and FACS staining characteristics

\begin{tabular}{|c|c|c|c|}
\hline Population & Subpopulation & Staining characteristics & When given in percent, calculated as proportion of \\
\hline T cells & - & $\mathrm{CD}^{+}$ & - \\
\hline T helper cells & - & $\mathrm{CD}^{+} \mathrm{CD}^{+}$ & $\mathrm{CD}^{+}$ \\
\hline Cytotoxic T cells & - & $\mathrm{CD}^{+} \mathrm{CD}^{+}$ & $\mathrm{CD}^{+}$ \\
\hline NK cells & - & $\mathrm{CD}^{-} \mathrm{CD} 16^{+} \mathrm{CD}_{5} 6^{+}$ & $\begin{array}{l}\text { Cells with typical lymphocyte size and } \\
\text { intracellular granulation }\end{array}$ \\
\hline iNKT cells & - & $\mathrm{CD}^{+}(\mathrm{TCR}) \mathrm{a} \beta^{+} \mathrm{Va}_{2} 4^{+} \mathrm{V} \beta 11^{+}$ & $\mathrm{CD}^{+}(\mathrm{TCR}) \mathrm{a \beta}^{+}$ \\
\hline NKT-like cells & - & $\mathrm{CD}^{+} \mathrm{CD}_{16}{ }^{+} \mathrm{CD}_{5} 6^{+}$ & $\mathrm{CD}^{+}$ \\
\hline NKT-like cells & $\mathrm{CD}^{+}{ }^{+}$NKT-like cells & $\mathrm{CD}^{+} \mathrm{CD}^{+} \mathrm{CD} 6^{+} \mathrm{CD}_{5} 6^{+}$ & $\mathrm{CD}^{+}$ \\
\hline NKT-like cells & $\mathrm{CD}^{+}$NKT-like cells & $\mathrm{CD}^{+} \mathrm{CD}^{+} \mathrm{CD} 16^{+} \mathrm{CD}_{5} 6^{+}$ & $\mathrm{CD}^{+}$ \\
\hline
\end{tabular}

cells in the population evaluated (numerator) and the remaining number of lymphocytes (denominator) and incorporating subjects as random effect (random intercepts) in the linear predictor of a generalized linear model with a binomial error distribution. In the mixed effects regression models, adjustments were evaluated for age, sex and smoking (where applicable). Smoking was evaluated both as a categorical variable (smoking status) and as a continuous variable (pack-years). Statistical analysis was performed using IBM SPSS Statistics (version 23) and, for calculating mixed effects regression models, statistical software package $\mathrm{R}$ (version 3.3.3; $\mathrm{R}$ Development Core Team, $\mathrm{R}$ foundation for Statistical Computing, Vienna, Austria).

\section{Results}

\section{Part 1 - Airway inflammation in COPD}

The proportion of NK cells was higher in the COPD group compared to both Ever-smokers and Non-smokers. In iNKT and NKT-like cells, no significant difference was found comparing COPD to Ever-smokers, but both these groups had increased proportions compared to Non-smokers (Fig. 2). NKT-like cell subpopulations exhibited the same pattern as the NKT-like population as a whole (Additional file 1: Table S3). The differential cell count showed no significant differences (Additional file 1: Table S1a).

\section{Part 2 - Separating the effect of smoking from that of COPD}

In NK cells, no significant difference was found between COPD current and COPD ex-smokers. However, both these groups had higher proportions of NK cells than ex-smokers with normal LF. Airway iNKT and NKT-like cells were significantly increased in COPD current compared to COPD ex-smokers, but there was no significant difference between COPD ex-smokers and ex-smokers with normal LF (Fig. 2). Among NKT-like cells, the CD8+ but not the CD4+ subpopulation was significantly increased in COPD current compared to COPD ex-smokers
(Fig. 3). The proportion of cytotoxic T-cells did not differ significantly between groups (Additional file 1: Table S2).

The mixed effects-regression analysis showed a statistically significant relationship between pack-years and increased proportions of NK, iNKT and NKT-like cells (OR (95\% CI): 1.02 (1.01-1.02), 1.11 (1.06-1.17) and 1.04 (1.02-1.06) respectively; $p<0.0001$ for all; among all subjects). Increased NK cells were also significantly associated with COPD (OR (95\% CI) 1.50 (1.05-2.13); $p=0.018$; among exsmokers, adjusted for pack-years).

The models also showed that the relative increase due to current smoking in the proportion of cytotoxic cells was largest for iNKT cells and smallest for NK cells (current smokers vs. ex-smokers; OR (95\% CI): iNKT cells 1007 (163-7119), NKT-like cells 9.14 (4.64-17.98); and NK cells 2.16 (1.39-3.35)).

The differential cell count of leukocytes showed increased numbers of macrophages in COPD current compared to COPD ex-smokers $(p=0.003)$. No other significant differences in differential cell counts were found (Additional file 1: Table S1a).

\section{Part 3 - COPD and a rapid/non-rapid of decline in lung function}

Between-group comparisons of the differential cell count of leukocytes, cell populations and subpopulations showed no significant differences (see Additional file 1: Tables S1, S2 and S3). The lack of association between rapid/nonrapid decline in LF and NK, iNKT and NKT-like cells was confirmed in the mixed effects-regression models, which included adjustments for age and smoking status.

\section{Discussion}

We have demonstrated increased proportions of NK cells in BALF from COPD patients compared to both Eversmokers and Non-smokers. This increase endured even after smoking cessation, as ex-smokers with COPD had significantly higher proportions of NK cells than ex-smokers with normal LF (Fig. 2). 


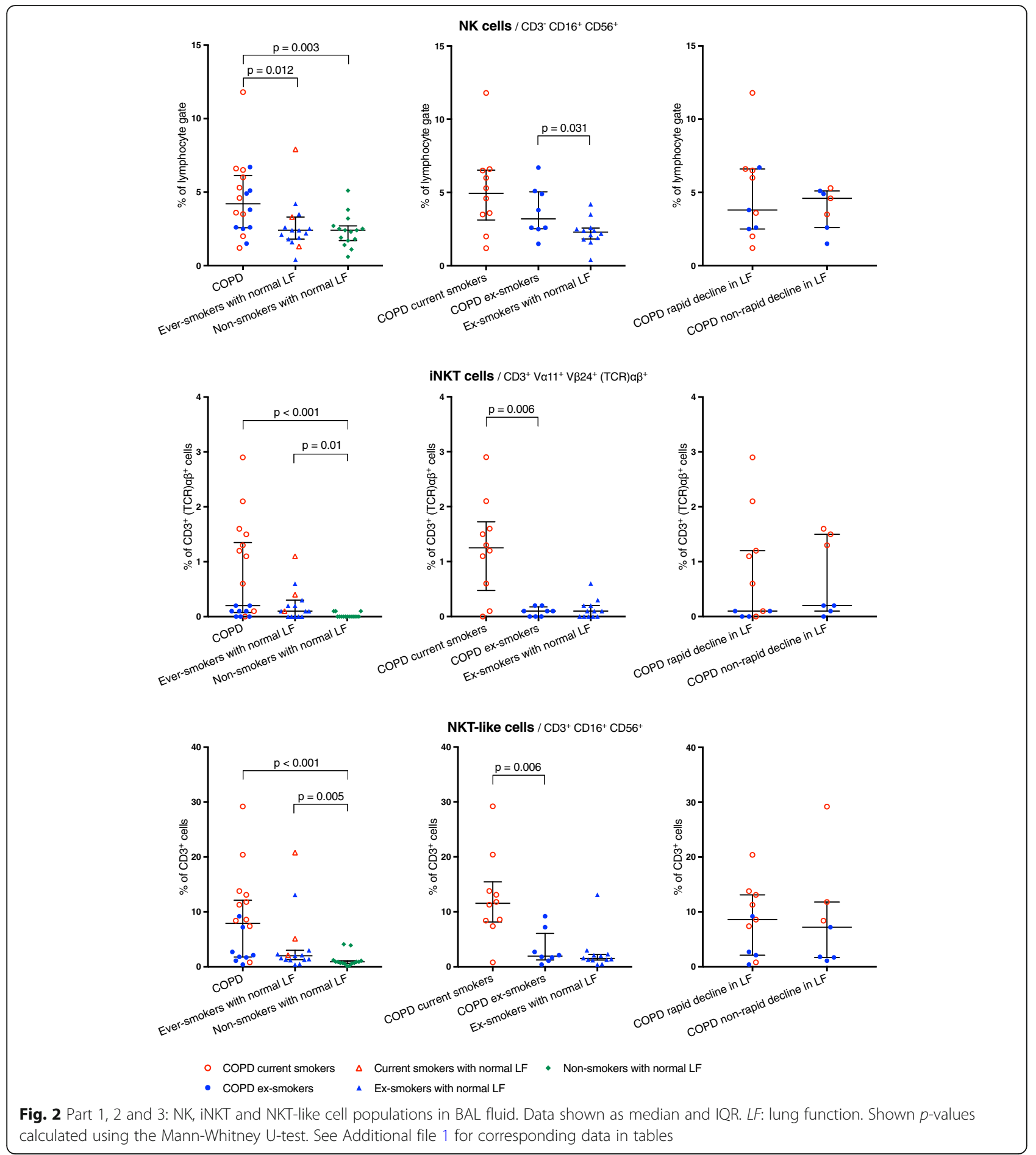

These results seemingly contradict those of the two previous studies which indicated that NK cell proportions in BALF depend on current smoking status rather than COPD $[19,20]$. However, neither of those studies included ex-smokers with normal LF as a control group and could thus not compare ex-smokers with and without COPD in order to identify enduring disease-specific alterations.
In the current study, the mixed model regression analysis showed that increased NK cells are associated both with cumulative smoking (pack-years) and with COPD. The latter association remained significant after adjustment for pack-years.

Our results echo those of a previous study of mice models, in which NK cells were identified as a candidate 


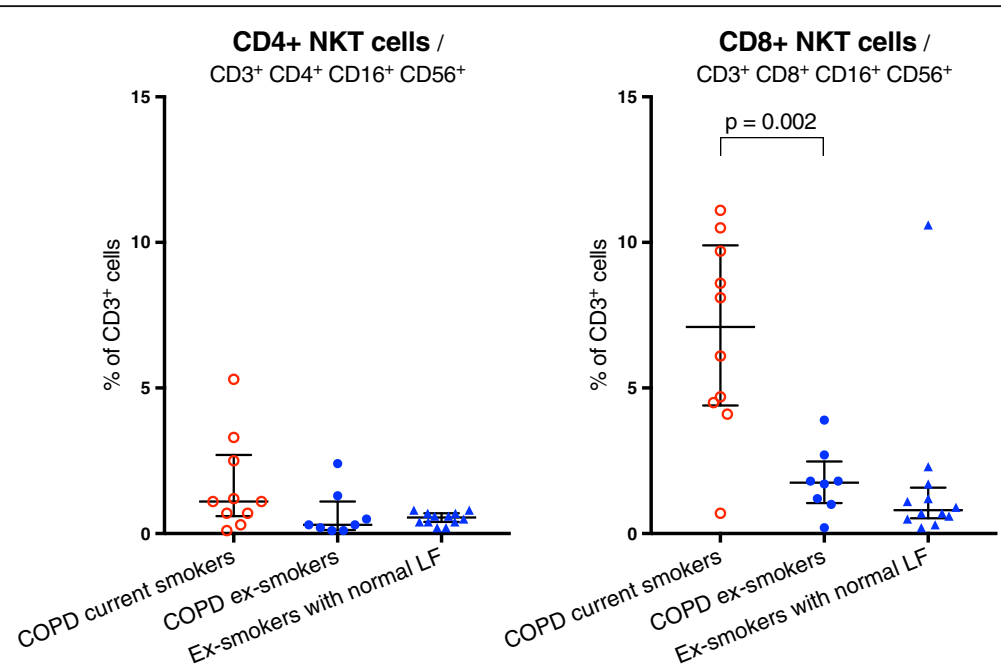

Fig. 3 Part 2: NKT-like cell subpopulations in BAL fluid. Data shown as median and IQR. LF: lung function. Shown p-values calculated using the Mann-Whitney U-test. See Additional file 1 for corresponding data in tables

persistence determinant of chronic airway inflammation following cigarette smoke exposure [21]. BALB/c mice were exposed to 6 cigarettes/day, 6 days/week for 16 weeks leading to an inflammatory profile in BALF similar to that of human COPD patients. After 12 weeks of non-exposure NK cells were still higher in the exposed group compared to controls.

Furthermore, in vitro experiments on cells from human lung tissue have shown that NK cells from COPD patients are more prone to kill autologous lung epithelial cells than NK cells from non-obstructive subjects [22, 23]. This spontaneous cytotoxicity also increased with worsening $\mathrm{FEV}_{1} \%$ predicted, supporting a potential role of NK cells in emphysema progression [22]. Increased expression of NK cell activating receptor ligands (such as MICA and MICB) by lung epithelial cells [22] as well as differences in the NK cells themselves have been proposed to explain these findings [23].

Taken together, these results indicate that NK cells may play an important role in the continued disease progression seen in COPD patients even after smoking cessation.

iNKT and NKT-like cells exhibited a pattern distinctly different from that of NK cells. In these cell populations, the main between-group difference was found not between COPD and non-COPD subjects, but rather between smokers and non-smokers.

Part 1 of the study showed increased iNKT and NKT-like cells in the two groups that consisted of smokers (COPD and Ever-smokers) compared to Non-smokers. In part 2, COPD current smokers had significantly higher proportions than COPD ex-smokers while no differences were seen between ex-smokers with COPD and ex-smokers with normal LF (Fig. 2). This pattern was then verified in the mixed effects-regression analysis where no statistical relationship between COPD and iNKT or NKT-like cells was found, but instead showed that these cells were heavily influenced by current smoking.

The definition of iNKT cells is not consistent throughout the literature. In this study, the term iNKT cells is used for the CD1d-dependent, $\alpha$-GalCer reactive, $\mathrm{V} \alpha 24^{+} \mathrm{V} \beta 11^{+}$ population which sometimes is also referred to as Type I NKT cells or Classical NKT cells [8]. Currently, the best way to identify iNKT in FACS is by using $\alpha$-GalCer-loaded $\mathrm{CD} 1 \mathrm{D}$ tetramers. In the current study $\mathrm{CD}^{+}(\mathrm{TCR}) \alpha \beta^{+}$ $\mathrm{V} \alpha 24^{+} \mathrm{V} \beta 11^{+}$was used to define this cell type. While these markers combined are fairly specific for iNKT cells, we cannot rule out that some other (non-invariant) $\mathrm{T}$ cells also expressed these markers and thus were included in the cell counts.

Functionally, iNKT cells are thought to play an important role in the pathogenesis of COPD. In a study on C57BL/6 mouse models, Pichavant et al. showed that exposure to cigarette smoke ( 5 cigarettes/day, 5 days/week, for up to 12 weeks) led to the accumulation of activated iNKT cells in the lungs [24]. In another study, BALB/c mice received weekly intranasal administrations of $\alpha$-GalCer in order to induce iNKT cell activation. After eight weeks, these mice models had developed pulmonary emphysema as well as molecular and inflammatory features similar to those of COPD [25].

Pichavant et al. also showed that smoking-related oxidative damage may be mediated through iNKT cells [24]. In a model of acute oxidative stress, wild type mice exposed to cumen hydroperoxide (CHP) - a compound that triggers 
lipid peroxidation - exhibited increased airway resistance and recruitment of neutrophils into the lungs. In knock-out mice lacking iNKT cells no change in LF or airway inflammation was seen following CHP exposure.

In humans, one previous study reported increased levels of iNKT cells in lung tissue from COPD compared to non-COPD subjects [7]. The results of the current study extend those findings by providing evidence of increased iNKT cells also in BALF and, more importantly, that such an increase may be associated more closely with current smoking than with COPD (Fig. 3).

NKT-like cells are not well-studied in the context of COPD. The results of two previous studies suggest that increased proportions of these cells are related to current smoking and not to COPD $[19,20]$. This was confirmed in the current study which additionally showed that increased NKT-like cells are associated not only with current but also with cumulative smoking (pack-years).

In the current study, NKT-like cells were defined as $\mathrm{CD}^{+} \mathrm{CD}^{+} 6^{+} \mathrm{CD} 6^{+}$cells. While this is a commonly used gating strategy for this population, it should be noted that it is likely to include cells not associated with the NKT cell lineage such as (TCR) $\gamma \delta^{+} \mathrm{T}$ cells. Also, the antibodies used in the analysis of NKT-like cell subpopulations do not cover all known variants and the results thereof should thus be interpreted with caution. However, it could be noted that the smoking-related increase seen in NKT-like cells as a whole seems to be driven mainly by $\mathrm{CD}^{+}$NKT-like cells which predominantly produce Th1type cytokines [26], while CD4 ${ }^{+}$NKT-like cells, capable of producing both Th1- and Th2-type cytokines [26], were not significantly increased by smoking (Fig. 3). These changes could contribute to tipping the Th1-Th2 balance in the lungs of smokers in a more pro-inflammatory direction. More functional studies of NKT-like cells are needed in order to better understand their role in COPD.

Contrary to our hypothesis, no significant differences in cytotoxic cell populations were found between COPD subjects with a rapid and a non-rapid decline in LF. One possible explanation could be that these clinically distinct phenotypes differ immunologically in aspects other than relative numbers of cytotoxic cells; e.g. immune cell activation, level of cytotoxicity and/or levels of regulatory immune cells. While beyond the scope of this study, these aspects should be investigated in further research on COPD rapid/ non-rapid decliners. Another explanation could be that the current study is simply underpowered to detect such differences. There are very few previous studies on immunological changes related to rate of decline in LF and there is no established definition of rapid/non-rapid decline in the literature, making power calculations highly uncertain.

In the current study, data on lymphocyte populations and subpopulations are presented in relative and not absolute cell numbers. The reason for this is that BAL recovery volumes, as in previous studies [19, 27], were found to be lower in COPD subjects compared to both non-smokers and ex-smokers with normal lung function [14]. We therefore believe that relative cell numbers better reflect differences in the inflammatory response when comparing these groups.

One strength of this study is the inclusion of not only Non-smokers, but also ex-smokers with normal LF acting as control groups. This enables comparisons of groups, between which only one major characteristic differ (e.g. ex-smokers with and without COPD), allowing us to better pinpoint the driving mechanism behind the reported immunological differences. Another strength is the use of a multivariable mixed effects-regression model to validate that between-group differences are indeed associated with the major difference in characteristic and not with other factors such as pack-years or age.

A limitation to this study is that women were underrepresented in the COPD rapid decline and Non-smokers groups (Table 1). Thus, we could not evaluate sex-specific differences, nor rule out that results were affected by these differences in group composition. There are interventional studies demonstrating sex-specific differences in the inflammatory response to tobacco smoke [28] as well as cross-sectional studies indicating that that women are more susceptible to tobacco smoke [29]. We have previously reported that the participation of COPD subjects in bronchoscopy studies is negatively affected by the large burden of co-morbidities within that group. As a result, the recruitment process might be disabled even if the basis for recruitment is large [14]. Nevertheless, to allow analyses stratified for sex, future studies should consider study population structure and size.

Another limitation is that the current study did not include a sufficient number of current smokers with normal LF. Because of this, comparisons between current smokers with and without COPD were not possible. And while disease specific changes are likely better detected comparing ex-smokers with normal LF to ex-smokers with COPD (current smoking is such a strong factor that it may mask changes related to the disease), it would have been a strength if such changes found could have been verified in a comparison between current smokers with and without COPD.

\section{Conclusions}

NK, iNKT and NKT-like cell proportions in BALF all increased with pack-years. Increased NK cells were also associated with COPD, while increased iNKT and NKTlike cells were associated with current smoking but not with COPD. Interestingly, NK cell percentages did not normalize in COPD subjects that had quit smoking, suggesting that these cells might play a role in the 
continued disease progression seen in COPD even after smoking cessation. Contrary to our hypothesis, no significant differences were found between COPD subjects with a rapid and a non-rapid decline in LF. Further research is needed to understand the underlying processes resulting in these two phenotypes.

\section{Additional file}

Additional file 1: Table S1a. Differential cell counts of leukocytes of in BAL fluid, given in number of cells $/ \mathrm{ml}^{*} 10^{4}$. Table S1b. Differential cell counts of leukocytes of in BAL fluid, given in percent. Table S2. Flow cytometry analysis of lymphocytes in BAL fluid, given in percent. Table S3. Flow cytometry analysis of NKT-like cell subpopulations in BAL fluid, given in percent. (DOCX $28 \mathrm{~kb}$ )

\section{Abbreviations \\ BAL: Bronchoalveolar lavage; BALF: Bronchoalveolar lavage fluid; Cl: Confidence interval; COPD: Chronic obstructive pulmonary disease; Ever-smokers: Ever-smokers with normal lung function; FACS: Fluorescence- activated cell sorting; $F_{E V}$ : Forced expiratory volume in one second; FVC: Forced vital capacity; GOLD: Global initiative for chronic obstructive lung disease; LF: Lung function; MMP9: Matrix metalloproteinase 9; NK cells: Natural killer cells; NKT-like cells: Natural killer T cell; Non-smokers: Non-smokers with normal lung function; OLIN COPD study: Obstructive Lung Disease in Northern Sweden Chronic Obstructive Pulmonary Disease study; OR: Odds ratio; VC: Vital capacity; a-GalCer: a- galactosylceramide}

\section{Acknowledgements}

The authors would like to thank Viktor Johansson Strandkvist, Helena Backman, Annika Johansson, Frida Holmström, Ove Björ, the OLIN studies and the Division of Respiratory Medicine and Allergy, Department of Medicine, Sunderby Central Hospital of Norrbotten, Luleå, Sweden for their contribution to the project.

\section{Funding}

Financial support was granted by the Swedish Heart-Lung foundation, the Västerbotten County Council, Visare Norr Fund/ Northern County Councils Regional Federation, Umeå University and King Gustaf V's and Queen Victoria's Freemason Foundation.

\section{Availability of data and materials}

The datasets used and/or analyzed during the current study are available from the corresponding author on reasonable request.

\section{Authors' contributions}

$J P, A B I, A L$ and $A F B$ designed the study. RL, ABI and AFB performed the bronchoscopies. JP performed the flow cytometry analysis. JP, ABI, ABu, AFB and JES helped develop the analysis plan and interpreted the results. JES drafted the manuscript. All authors read and approved the final manuscript.

\section{Ethics approval and consent to participate}

Informed consent was obtained from all volunteers after verbal and written information and the study was approved by the local Ethics Committee at Umeå University, Sweden, and performed according to the declaration of Helsinki.

\section{Consent for publication}

Not applicable.

\section{Competing interests}

The authors declare that they have no competing interests.

\section{Publisher's Note}

Springer Nature remains neutral with regard to jurisdictional claims in published maps and institutional affiliations.

\section{Author details}

'Department of Public Health and Clinical Medicine, Division of Medicine, Umeå University, 90187 Umeå, Sweden. ${ }^{2}$ Swedish Defence Research Agency, Division of CBRN Defence and Security, Umeå, Sweden.

Received: 21 September 2018 Accepted: 19 November 2018 Published online: 07 December 2018

\section{References}

1. Hogg JC. Pathophysiology of airflow limitation in chronic obstructive pulmonary disease. Lancet. 2004;364:709-21.

2. Traves SL, Smith SJ, Barnes PJ, Donnelly LE. Specific CXC but not CC chemokines cause elevated monocyte migration in COPD: a role for CXCR2. J Leukoc Biol Society for Leukocyte Biology. 2004;76:441-50.

3. Barnes PJ. Alveolar macrophages as orchestrators of COPD. COPD: J Chron Obstruct Pulmon Dis. 2004;1:59-70.

4. Saetta M, Di Stefano A, Turato G, Facchini FM, Corbino L, Mapp CE, et al. CD8+ T-lymphocytes in peripheral airways of smokers with chronic obstructive pulmonary disease. Am J Respir Crit Care Med. 1998;157:822-6.

5. Roos-Engstrand E, Pourazar J, Behndig AF, Blomberg A, Bucht A. Cytotoxic T cells expressing the co-stimulatory receptor NKG2 D are increased in cigarette smoking and COPD. Respir Res. 2010;11:S17-1.

6. Rovina N, Koutsoukou A, Koulouris NG. Inflammation and immune response in COPD: where do we stand? Mediat Inflamm. 2013;2013:413735-9.

7. Kim EY, Battaile JT, Patel AC, You Y, Agapov E, Grayson MH, et al. Persistent activation of an innate immune response translates respiratory viral infection into chronic lung disease. Nat Med. 2008;14:633-40.

8. Godfrey DI, MacDonald HR, Kronenberg M, Smyth MJ, Van Kaer L. Opinion: NKT cells: what's in a name? Nat Rev Immunol. 2004;4:231-7.

9. Tang Y. Increased numbers of NK cells, NKT-like cells, and NK inhibitory receptors in peripheral blood of patients with chronic obstructive pulmonary disease. Chest. 2016;149:A380.

10. Stockley RA, Mannino D, Barnes PJ. Burden and pathogenesis of chronic obstructive pulmonary disease. Proc Am Thorac Soc. 2009;6:524-6.

11. Koskela J, Katajisto M, Kallio A, Kilpeläinen M, Lindqvist A, Laitinen T. Individual FEV 1Trajectories can be identified from a COPD cohort. COPD: J Chron Obstruct Pulmon Dis. 2016;13:425-30.

12. Friedlander AL, Lynch D, Dyar LA, Bowler RP. Phenotypes of chronic obstructive pulmonary disease. COPD. 2007;4:355-84.

13. Lindberg A, Lundbäck B. The obstructive lung disease in northern Sweden chronic obstructive pulmonary disease study: design, the first year participation and mortality. Clin Respir J. 2008;2:64-71.

14. Lindberg $\mathrm{A}$, Linder R, Backman $\mathrm{H}$, Eriksson Ström J, Frølich A, Nilsson U, et al. From COPD epidemiology to studies of pathophysiological disease mechanisms: challenges with regard to study design and recruitment process: respiratory and cardiovascular effects in COPD (KOLIN). Eur Clin Respir J. 2017:4:1415095.

15. Vogelmeier CF, Criner GJ, Martinez FJ, Anzueto A, Barnes PJ, Bourbeau J, et al. Global Strategy for the Diagnosis, Management, and Prevention of Chronic Obstructive Lung Disease 2017 Report. GOLD Executive Summary. Am J Respir Crit Care Med. 2017;195:557-82.

16. Standardization of Spirometry, 1994 Update. American Thoracic Society. Am J Respir Crit Care Med. 1995;152:1107-36.

17. Berglund E, Birath G, Bjure J, Grimby G, Kjellmer I, Sandqvist L, et al. Spirometric studies in Normal subjects I. Acta Med Scand. 2009;173:185-92.

18. Roos-Engstrand E, Pourazar J, Behndig AF, Bucht A, Blomberg A. Expansion of CD4+CD25+ helper T cells without regulatory function in smoking and COPD. Respir Res. 2011;12:74.

19. Forsslund H, Mikko M, Karimi R, Grunewald J, Wheelock ÅM, Wahlström J, et al. Distribution of T-cell subsets in BAL fluid of patients with mild to moderate COPD depends on current smoking status and not airway obstruction. Chest. 2014;145:711-22.

20. Hodge G, Mukaro V, Holmes M, Reynolds PN, Hodge S. Enhanced cytotoxic function of natural killer and natural killer T-like cells associated with decreased CD94 (Kp43) in the chronic obstructive pulmonary disease airway. Respirology. 2013;18:369-76.

21. Hansen MJ, Chan SPJ, Langenbach SY, Dousha LF, Jones JE, Yatmaz S, et al. IL-17A and serum amyloid A are elevated in a cigarette smoke cessation model associated with the persistence of pigmented macrophages, neutrophils and activated NK cells. PLoS ONE. 2014;9:e113180. 
22. Freeman CM, Stolberg VR, Crudgington S, Martinez FJ, Han MK, Chensue SW, et al. Human CD56+ cytotoxic lung lymphocytes kill autologous lung cells in chronic obstructive pulmonary disease. PLoS ONE. 2014;9:e103840.

23. Finch DK, Stolberg VR, Ferguson J, Alikaj H, Kady MR, Richmond BW, et al. Lung Dendritic Cells Drive NK Cytotoxicity in Chronic Obstructive Pulmonary Disease via IL-15Ra. Am J Respir Crit Care Med. 2018;198:114050. rccm.201712-25130C.

24. Pichavant $\mathrm{M}$, Rémy $\mathrm{G}$, Bekaert $\mathrm{S}$, Le Rouzic $\mathrm{O}$, Kervoaze G, Vilain E, et al. Oxidative stress-mediated iNKT-cell activation is involved in COPD pathogenesis. Mucosal Immunol. 2014;7:568-78.

25. Tsao C-C, Tsao P-N, Chen Y-G, Chuang Y-H. Repeated activation of lung invariant NKT cells results in chronic obstructive pulmonary disease-like symptoms. PLoS One. 2016;11:e0147710

26. Urbanowicz RA, Lamb JR, Todd I, Corne JM, Fairclough LC. Altered effector function of peripheral cytotoxic cells in COPD. Respir Res. 2009;10:53.

27. Löfdahl JM, Cederlund K, Nathell L, Eklund A, Sköld CM. Bronchoalveolar lavage in COPD: fluid recovery correlates with the degree of emphysema. Eur Respir J. 2005;25:275-81.

28. Faner R, Gonzalez N, Cruz T, Kalko SG, Agustí A. Systemic inflammatory response to smoking in chronic obstructive pulmonary disease: evidence of a gender effect. PLOS ONE. 2014;9:e97491.

29. Sørheim I-C, Johannessen A, Gulsvik A, Bakke PS, Silverman EK, DeMeo DL. Gender differences in COPD: are women more susceptible to smoking effects than men? Thorax. 2010;65:480-5.

Ready to submit your research? Choose BMC and benefit from:

- fast, convenient online submission

- thorough peer review by experienced researchers in your field

- rapid publication on acceptance

- support for research data, including large and complex data types

- gold Open Access which fosters wider collaboration and increased citations

- maximum visibility for your research: over $100 \mathrm{M}$ website views per year

At $\mathrm{BMC}$, research is always in progress.

Learn more biomedcentral.com/submissions 